Historic, Archive Document

Do not assume content reflects current scientific knowledge, policies, or practices. 

62,43

$1928^{\circ}$

ILLUSTRATED AND DESORIPAIDEA R PRICE LIST

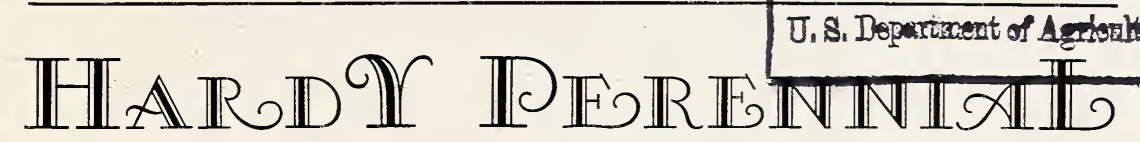
FLOWERINR PIAATS ANNUAL FLOIVERING PLANTS VEGETABLE PLANTS

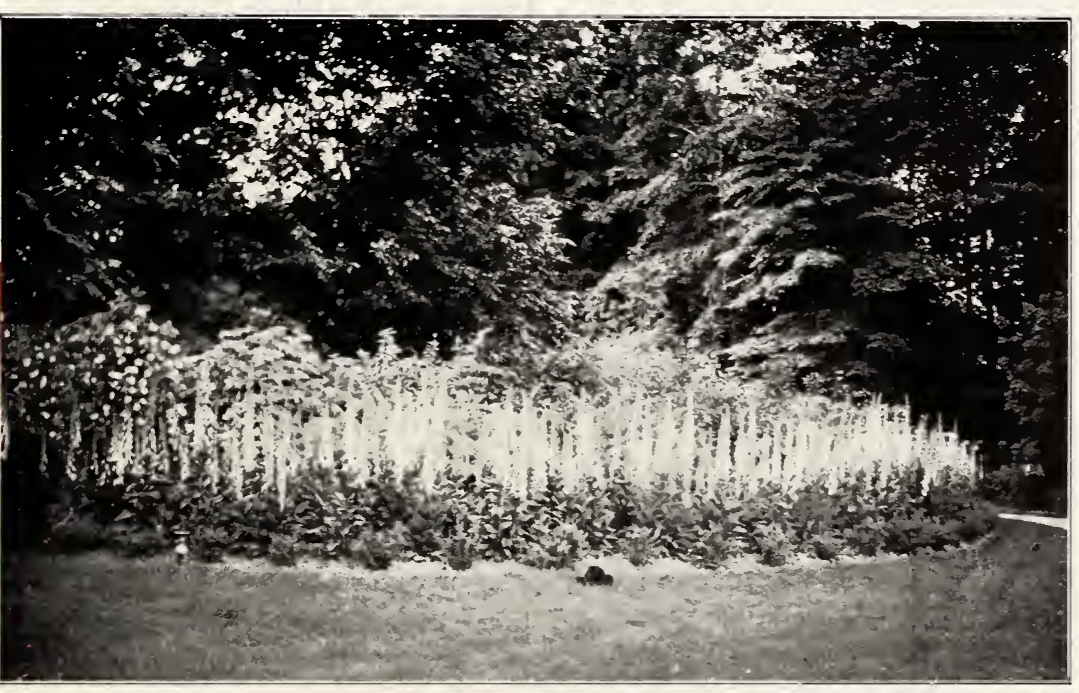

PROSPECTIVE CUSTOMERS ARE INTITED TO VISIT OUR GARDENS

\section{DERTINS $\mathbb{B}$ BDTHERS} POSTOFFICE ADDRESS:

\section{NORTH ST. PALL, MINNESOT.A}

GARDENS:-ST. PAUL-STILLIVATER ROAD (HIGHWAY 45) RAMSEY COUNTY, MINNESOTA 


\section{THANK YOU}

We wish to thank all our customers and friends for their patronage and kindness in retting their friends and neighbors know about our plants and better service. During the past year we have added about 25 varieties of perennials to our stock. To help our customers in selecting their annual plants we are giving a brief description of each kind. Please note that we will be able to supply many of the better varieties of annuals in separate colors, thus making it possible for our patrons to work out color schemes in their gardens.

\section{NURSERY INSPECTION}

Our nursery is regularly inspected by an authorized inspector from the Minnesota State Department of Agriculture. Our Certificate of Inspection is on file at our nulsery and may be seen by any one. These certificates are a protection to our customers. All plants apparently affected with injurious insects or diseases must be destroyed before the certificate is given.

It is our desire to sell only well grown, healthy plants which are sure to grow even under unfavorable conditions. There are a number of reasons why plants do not always grow when transplanted, for example, lack of firming the soil around the roots; too little moisture in the soil at time of planting, or soon after, before the roots have become established; exposure of roots to sun or wind; improper care of plants after being received; poor soil or poorly prepared soil; planting too deep or too shallow; some plants are not transplanted very successfully.

We endeavor to purchase all our seeds and stocks from reliable sources, and are making every effort to keep our plants true to name, but on account of the many conditions due to natural causes, which are beyond our control, it is impossible to guarantee that every plant (especially when grown from seed) will be true to color or type.

\section{GUARANTEE}

We guarantee that all plants sold by us will reach you in good condition. Should we make a mistake in filling your order we will be glad to make a satisfactory adjustment. Please call our attention to mistakes within five days. Except as above stated we do not in any way guarantee the hardiness or growth of any plant and cannot be responsible for the crop or for a greater sum than the original cost.

\section{SHIPMENT}

Small orders can be sent by parcel post, but we recommend shipment by express. When sent by express we can leave more dirt on the roots at time of packing, and this is important.

Our prices do not include postage or express charges. If plants are wanted by parcel post add 10 cents for the first plant and 5 cents for each additional plant.

\section{TERMS}

Cash should accompany all orders. Remittances may be made by Postoffice or Express Money Orders. If personal check is sent please allow for exchange charges. All orders received subject to shortages and conditions beyond our contol.

\section{PRICES}

All prices are net. Our prices are low for the high quality plants we sell. In nearly all cases the plants have been transplanted. We reserve the right to charge extra for field selection of plants by the customer. All prices in this catalog subject to change without notice.

\section{HARDY (PERENNIAL) PLANTS}

The demand for Hardy Plants is increasing. Many people desire to avoid planting and selecting new plants each year, but we should not be misled by the idea that Hardy Plants do not need any care after being once planted. No plant will do its best when neglected. There are Hardy Plants suited for nearly every situation; in the border, in beds, amongst shrubbery, and in odd corners. Very few Hardy Plants bloom the entire season, and it is often desirable to plant some annuals with them to insure a greater supply of bloom.

It is generally best to put from three to six or more plants of each variety in a group rather than to plant singly, as this will give a more effective display. The use of white flowered varieties helps to prevent the clashing of colors.

\section{CULTURAL DIRECTIONS}

For the best results perennials should be planted in good garden soil, with plenty of fertility and moisture. Thorough preparation of the soil is essential and very important. Perennials generally stay in the same place for several years and if the soil is carelessly prepared before planting it is impossible to overcome the bad effects unless the entire garden is made over. Keep the ground cultivated to conserve the moisture and keep the weeds down.

An ample supply of moisture and plant food produces a superior quality of flowers.

Hardy Plants may be transplanted at any time during the growing season. If you prefer to plant in the spring do it just as early as possible so that the plants will be well established before they start to bloom. A great many people prefer to plant in the fall after the blooming period is over. Good results may be obtained by either method. It is not advisable to move a plant when it is in bloom.

We have found that when the dead blossoms are cut off and not allowed to produce seed, the bloom ing period is longer, and the plants make a better growth.

Winter Protection: In some locations it is not absolutely necessary to give perennials any winter protection, but most growers feel that all should be given at least a little protection, such as a covering of loose marsh hay. straw or leaves. Do not pack the covering down. The object of the covering is to prevent alternate thawing and freezing in the spring.

Common Names of the Hardy Flowering Plants Listed in this Catalog, followed by the number under which they will be found.

\begin{tabular}{|c|c|}
\hline Alaska Daisy 6575 & Coreopsis \\
\hline Anchusa 6121 & Cornflower $6+30$ \\
\hline Asters 6240 & Crimson Eye 7121 \\
\hline Breath 7030 & Dusty Miller \\
\hline Balloon Flower 7560 & Euphorbia 6930 \\
\hline Basket of Gold 6100 & False Chamomile 6311 \\
\hline Bearded Tongue 7470 & False Indigo 6280 \\
\hline Bedding Pansies 7990 & Flax 7280 \\
\hline Blanket Flower 6960 & Fox Glove 6824 \\
\hline Bleeding Heart 6801 & French Honeysuckle \\
\hline Blue Bonnet 7721 & Gaillardia \\
\hline Candy Tuft 7190 & Giant Daisy $76+7$ \\
\hline Canterbury Bells 6340 & Golden Glow 7675 \\
\hline Cup \& Saucer C. Bells 6350 & Hardy Marguerite \\
\hline Carnation & Hare Bell \\
\hline Chimney Bell Flower 635 & Hollyhocks 7130 \\
\hline Chinese Lantern 7540 & Honeysuckle 6160 \\
\hline Columbine 6160 & Hybrid Sweet William \\
\hline Bells 7 & \\
\hline
\end{tabular}

Iceland Poppy $7+30$

Larkspur 6650

Lily of Valley 6620

Lupine 7310

Mallow 7120

Maltese Cross 7321

Meadow Rue 7880

Meadow Sage 7681

Monkshood 6020

Mullein Pink 7328

Moonpenny Daisy 6590

Oriental Poppy 7441

Painted Daisy $76+0$

Peach Be'ls 6360

Pearl 6012

Pinks 6700

Plumy Bleeding Heart 6802

Purple Cone Flower 7670
Ragged Robin 7327

Red Hot Poker 7921

Rock Cress 6180

Rose Mallow 7120

Rosy Milfoil 6011

Salvia 7681

Scabiosa 7721

Sea Holly 6910

Sea Lavender 7831

Shasta Daisy 6575

Sneeze Weed 7041

Snow-in-Summer 6460

Speed well 7960

Sweet William 6750

Turtle Head 6470

White Daisy 6590

Yellow Cone Flower 7671

WE PREFER TO SHIP PLANTS BY EXPRESS SO THAT SOIL MAY BE LEFT ON ROOTS. 


\section{HARDY PERENNIAL PLANTS}

\section{ABBREVIATIONS USED IN THE DESCRIPTIONS}

B-After the name of a plant indicates that the plant is a biennial, that is, as a rule the plant does not blossom until the second year of its growth, blooming only the one season and then dying. Occasionally, however, if seed is not allowed to mature, the plant will live for several seasons.

$\mathrm{P}$-Indicates a perennial or Hardy Plant, that is, a plant which under favorable conditions will grow and blocm for several years.

$\because$ Before a Number-The flowers can be cut and used in bouquets.

Name of months or season indicates time of blossoming.

\section{ACHILLEA (The Pearl)}

$\approx 6012$ PTARMICA-P.; 2 ft.; all summer. An easily grown plant, bearing many small double white flowers. Each 20 cents; 2 for 35 cents.

※6011 MILLEFOLIUM ROSEUM-Rosy Milfoil, P.; 18 inches; all summer; a rery hardy plant bearing dense heads of small pink flowers. The flowers will keep their color best if grown in partial shade. Each 20 cents; 2 for 35 cents.

\section{ACONITUM (Monkshood)}

6020 FISCHERI-P.; 4-6 ft.; Sept.; a good plant for the border bearing blue flowers. The plant prefers a rich soil. It will grow in sun but the ilowers will last longer in the shade. It needs some winter protection. As Acoustes contains poisonous substances they should be kept away from children. Each 20 cents; 2 for 35 cents.

\section{AGROSTEMMA (Mullein Pink)}

$\approx 6070$ CORONARIA (Dusty Miller)-B.; $1.2 \mathrm{ft}$; Tune-September; bright colored long stemmed flowers similar to Pinks. Each 20 cents; 2 for 35 cents.

\section{ALYSSUM (Basket of Gcld)}

$\because 6100$ SAXATILE COMPACTUM-P.; $1 \mathrm{ft}$.; ear-

ly spring a border plant producing masses of bright yeilow flowers, foliage a gray-green. Seed pods may be dried and used in winter bouquets. Each 20 cents, 2 for 35 cents.

:6101 ARGENTUM (Mad Wort)-Dwarf, dense grower, yellow flowers; all summer. Each 35 cents.

\section{ANCHUSA}

*6121 ITALICA-Dropmore Variety, P.; 3-5 ft.; JuneSept. A plant with grayish rough shining foliage, and producing many beautiful gentian blue flowers. Succeeds best in partial shade. Each 20 cents; 2 for 35 cents.

\section{ANTHEMIS (Hardy Marguerite)}

$\because 6140$ KELWAYI-P.; 2 ft.; all summer; vellow daisylike flowers. 2 year old plants. Each 30 cents; 2 for 50 cents.

\section{AQUILEGIA (Columbine)}

$\because$ Cclumbine (often called Honeysuckle); P.; 2-3 ft.; May-July; a very popular hardy perennial producing an abundance of graceful flowers on long stems. Can be used in rock gardens.

6160 MIXED VARIETIES.

6161 COERULEA (Rocky Mountain Columbine)-Blue. 6162 CHRYSANTHA-Flowers golden yellow.

6163 LONG SPURRED PINK HYBRIDS.

6164 MRS. SCOTT ELLIOTT'S STRAIN.

6166 CHRYSANTHA GRANDIFLORA ALBA; white.

Any AQUILEGIA, LARGE PLANTS, EACH 50 CENTS AND UP.

\section{ARABIS (Rock Cress)}

6180 ALPINA (Rock Cress)-P.; 6.8 inches; early spring; a pretty plant having gray foliage and producing a mass of small white flowers. Suitable for edgings and rockeries. Each 20 cents; 2 for 35 cents; large plants 30 cents and up.

\section{BAPTISIA (False Indigo)}

6280 AUSTRALIS-P.; $2-4$ ft.; June; racemes of pea shaped indigo blue flowers; deeply cut foliage. Thrices in any soil, and prefers free exposure to the sun. Each 20 cents; 2 for 35 cents.

\section{BOLTONIA (False Chamomile)}

※6312 LATISQUAMA-P.; 5 ft.; July-Oct.; tall leafy plants bearing large clusters of pink daisylike flowers. They prefer a rich soil and are of the easiest culture. Each 25 cents; 2 for 45 cents.

\section{CAMPANULA}

*MEDIUM-Canterbury Bells; B.; 12.18 inches; June-July; bell-shaped flowers arranged along a stem. They are suitable for mass effects and will last longer if planted in a half shady place. They transplant easily. They will last well as cut flowers and are excellent for filling vases.

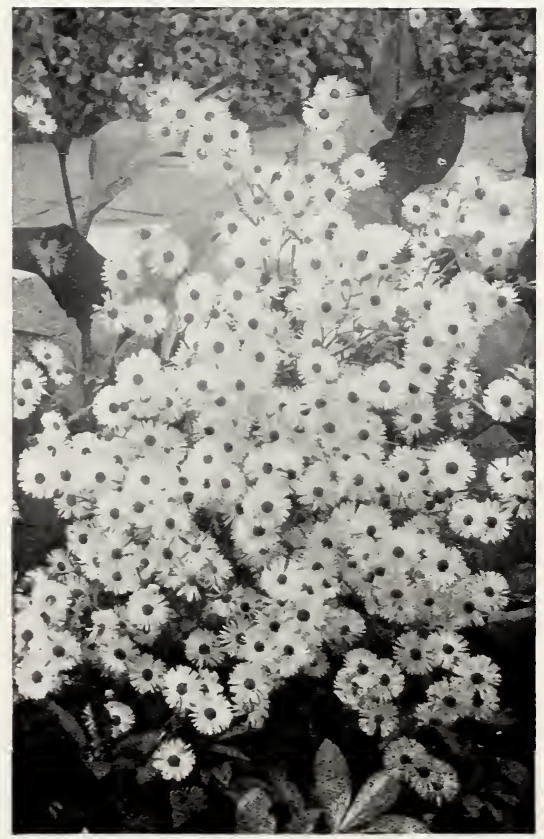

BOLTONIA 
6340 MIXED VARIETIES. 6342 SINGLE WHITE. 6341 SINGLE BLUE. 6343 SINGLE ROSE.

6350 CALYCANTHEMA-Cup and Saucer form of Canterbury Bells, mixed colors.

ALL CANTERBURY BELLS, EACH 20 CENTS; 2 FOR 35 CENTS

※6345 CARPATICA-Harebell; P. 9 inches; July to October; dwarf; compact tufts; flowers clear blue; a good plant for rockeries. Each 25 cents; 2 for 45 cents.

※6346 ALBA-A white form of Harebell. Ecah 20 cents 2 tor 35 cents.

6355 PYRAMIDALIS-Chimney Bellflower; P.; 5-6 ft.; flowers blue. Each 20 cents; 2 for 35 cents.

*6360 PERSICIFOLIA-Peach Bells; P.; 2-3 ft.; one of the best perennial Campanulas, mixed colors. Each 20 cents; 2 for 35 cents.

\section{CARNATION}

※6370 GRENADIN-P.; all summer; strong fragrance; quite hardy with ordinary protection; mixed colors. Each 20 cents; 2 for 35 cents.

\section{CENTAUREA (Corn Flower)}

*PERENNIAL CORN FLOWER-P.; $2 \mathrm{ft}$; June to September; of easy culture, preferring an open, sunny position. Thistle-like flowers.

6430 MONTANA BLUE.

6431 MONTANA WHITE.

EACH 20 CENTS; 2 FOR 35 CENTS.

\section{CERASTIUM (Snow in Summer)}

6460 TOMENTOSUM-P.; 4 inches; early summer. A low growing plant with silvery foliage and white flowers. Suitable for rockeries; for carpeting dry, sunny places and for covering graves. Each 20 cents; 2 for 35 cents.

\section{CHELONE (Turtle Head)}

*6470 HYBRIDA (Pentstemon Torreyi)-P.; $3 \mathrm{ft}$.; July August. Long spikes of coral pink colored flowers. Half shaded places are preferred and very dry ground should be avoided. It is often advisable to give a heavy mulch of 4 or 5 inches during the growing season. The surface roots feed in the mulch. Each 20 cents; 2 for 35 cents.

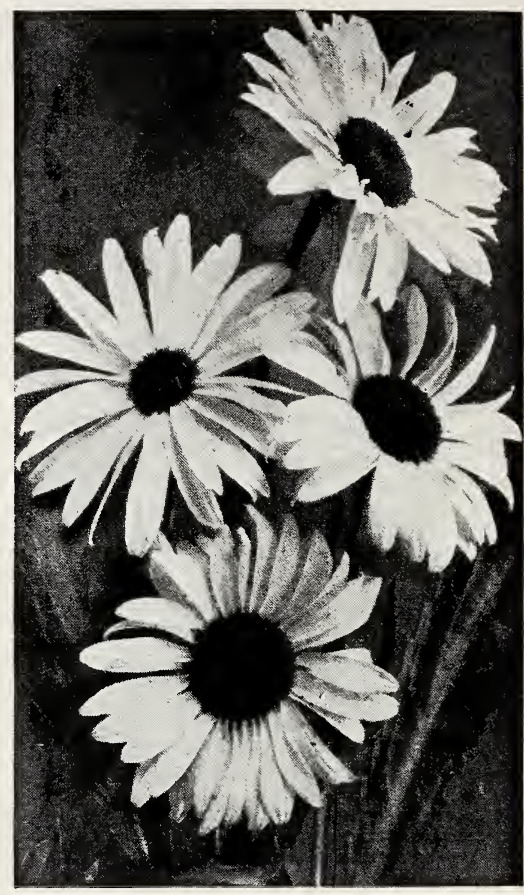

SHASTA DAISY

CHRYSANTHEMUM (Daisy)

*6575 SHASTA DAISY (Alaska)-P.; 2 ft.; all summer; beautiful large white daisy-like flowers with yellow centers. Each 20 cents; 2 for 35 cents. Large plants 30 cents and up.

*6590 White DAISY (Moonpenny Daisy) - P.; 2-3 ft.; all summer; a form similar to the above but smaller. Produces very many long stemmed flowers. Each 20 cents; 2 for 35 cents.

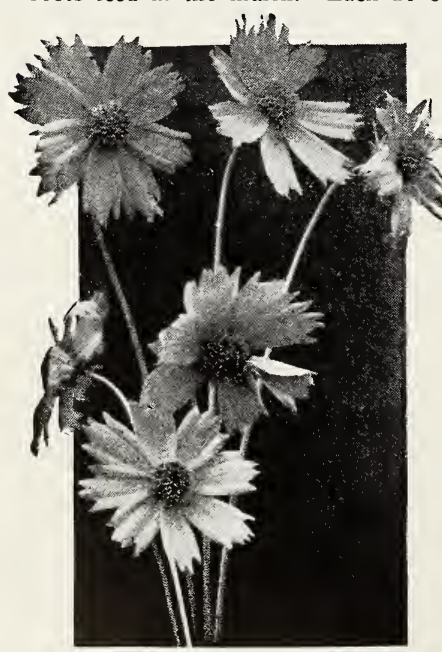

SINGLE COREOPSIS

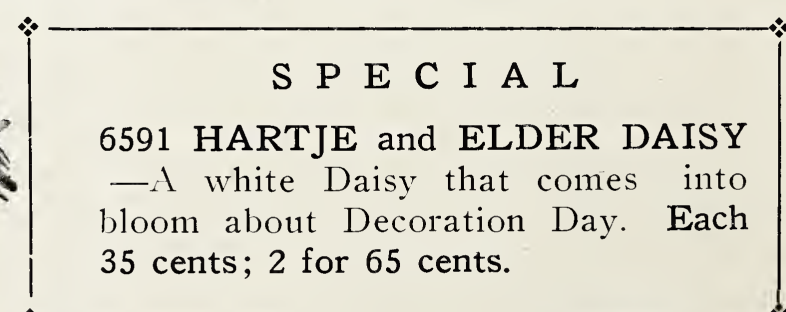

CONVALLARIA

※6620 LILY OF THE VALLEY-Pips, Dozen 40 cents.

\section{COREOPSIS}

*6630 LANCEOLATA GRANDIFLORA-Coreopsis; P.; 2 -3 ft. all summer; large bright yellow flowers on long stems. Each 20 cents; 2 for 35 cents.

*6631 DOUBLE FORM OF ABOVE-Grown from divisicns. Each 40 cents. 


\section{DELPHINIUMS (Larkspur)}

$\therefore$ HARDY LARKSPUR-P.; $1-3$ ft.; June to frost. A very popular flower which should be in every garden. Whi'e it prefers a deep, rich sandy loam it will thrive in any good garden soil. Excellent for cut flowers.

\section{MIXED VARIETIES.}

6660 BELLADONNA-Turquois blue.

6661 BELLAMOSUM-Deep blue.

6662 GOLD MEDAL HYBRIDS-Various shades of blue.

An excellent strain.

6663 CHINENSE-A dwari species with fine feathery foliage and gentian blue flowers.

6665 BLUE BUTTERFLY-Similar to Chinense.

6666 LAVENDER BUTTERFLY-Lavender flowers.

6667 WHITE BUTTERFLY - White flowers.

6671 FORMOSUM-Blue with white eye.

PRICES OF DELPHINIUUMS, ANY VARIETY, EACH 20 CENTS; 2 FOR 35 CENTS; LARGE PLANTS 35 CENTS EACH.

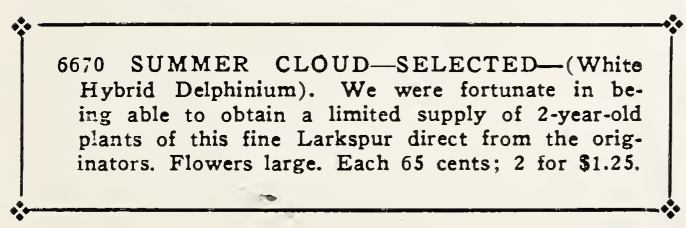

\section{DIANTHUS (Pinks)}

$\because 6701$ PLUMARIUS SEMPERFLORENS-An ..evertlooming Hardy Garden Pink.; 1 ft.; all summer; Pinks are oi the easiest culture, preferring a warm soil. They are universal favorites and make excellent border plants. Each 20 cents; 2 for 35 cents.

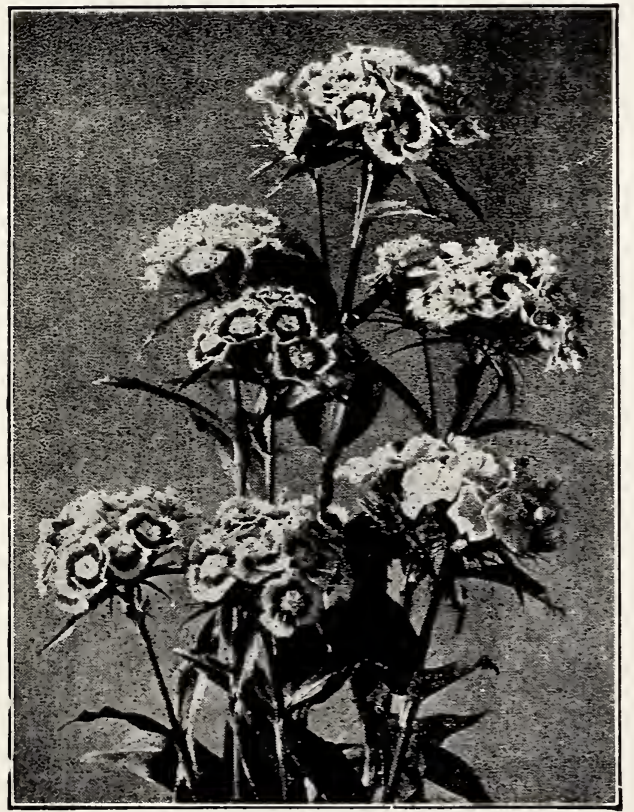

SWEET WILLIAM

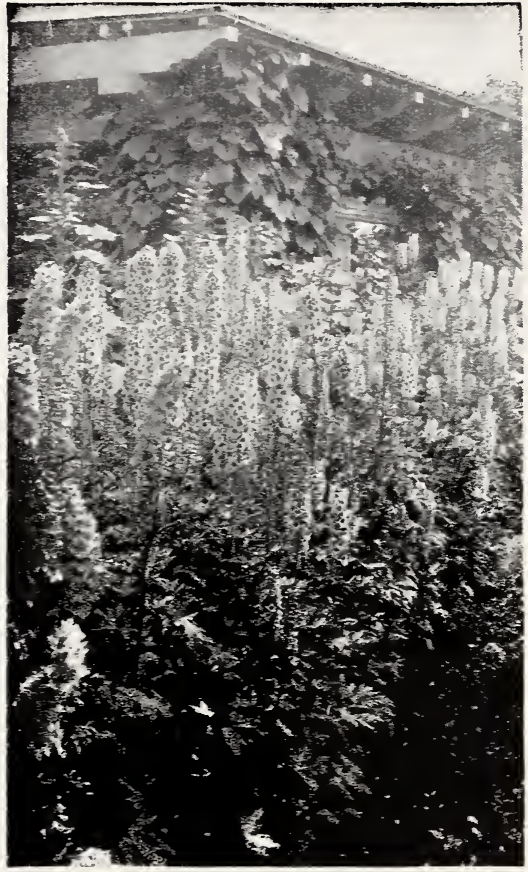

DELPHINIUMS

6702 PLUMARIUS-Mrs. Sinkins; white flowers. All do not come true. Each 20 cents: 2 for 35 cents.

6704 PLUMARIUS CYCLOPS-Clore pink, mixed cotors. Each 20 cents: 2 for 35 -cents 6705 PLUMARIUS CAESIUS Cliff: Pink flowers delicate rose color - Each 20 cents; 2 for 35 cents.

6706 PLUMARIUS: DOUBLE: WHITEFrom cuttings. Each 25. cents.

6707: PLUMARIUS, DOUBLE LIGHT PINK- From cuttings. - Each 25 cents. $\because 6725$ DIANTHUS LATIFOLIUS ATROC. NINEUS - A hybrid Sweet William; P.; 1 ft. ; all summer until frost: beautiful dee crimson outdoor flower similar to Double Pinks; suitable for borders or solid beds. Each 20 cents: 2 for 35 cents.

6726 DIANTHUS LATIFOLIUS-Similar to above except in color of flowers. Prices the same.

6730 LIANTHUS DENTOSUS HYBRID. US -A red Siberian variety blooming in July. Each 20 cents; 2 for 35 cents.

6731 DIANTHUS DELTOIDES-Each 20 cents; 2 for 35 cents.

\section{DIANTHUS BARBATUS} (SWEET WILLIAM)

$\therefore$ SWEET WILLIAM-B.; 18-24 inches : Iune to July; often blooming longer if not allowed to mature seed.

6750 MIXED VARIETIES

6751 SCARLET BEAUTY.

6752 PINK BEAUTY.

6754 VELVET BLACK MAROON.

6:55 ATRO SANGUINEUS-Blood Red.

6775 DOUBLE WHITE.

6776 DCUBLE ROSE.

6777 DOUBLE BLOOD RED.

PRICES ON ANY OF ABOVE; EACH 20 CENTS; 2 FOR 35 CENTS; 6 FOR $\$ 1$. 


\section{DICENTRA (Bleeding Heart)}

$\because 6801$ SPECTABILIS-P.; 1 -2 ft.; spring; attractive hardy perrennial plants with much cut foliage and long racemes of graceful pink heart-shaped flowers. Easily cultivated; desires part shade. Each, 50 cents and 75 cents.

6802 EXIMAE-Plumy Bleeding Heart; 15 inches; April to August; foliage finely cut. Each 25 cents.

\section{DIGITALIS (Fox Glove)}

6824 GLOXENIAEFOLIA-B.; $2-4$ ft.; a popular old fashioned flower. Flowers in spikes; mixed colors. Each 20 cents; 2 for 35 cents.

\section{ERYNGIUM (Sea Holly)}

6910 AMETHYSTINUM-1 1/2-3 ft.; July to Sept. Finely cut foliage with bluish-green shoots terminating with amethyst blue flowers. May be dried and used for winter boquets. Each 20 cents; 2 for 35 cents; large plants 30 cents.

\section{EUPHORBIA}

6930 POLYCHROMA-1 ft.; April-May. The floral leaves are different shades of yellow at flowering time. The plant is compact

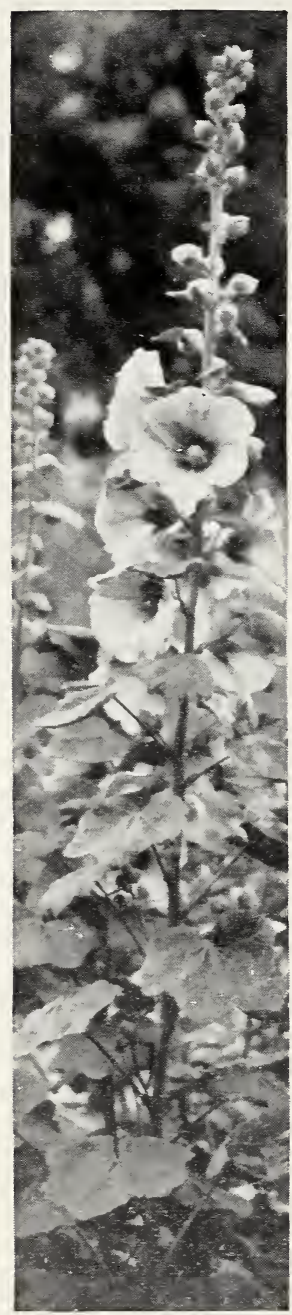

HOLLYHCCKS

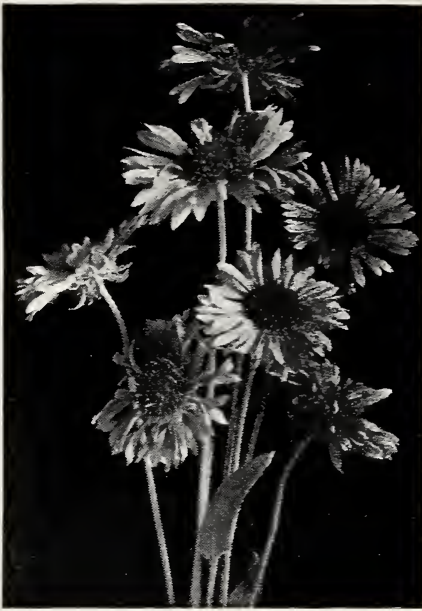

GAILLARDIA and one of the best herbaceous perrennials. Each 35 cents.

GAILLARDIA (Blanket Flower)

*6960 GRANDIFLORA-P.; 2 ft.; all summer; a plant of easy culture, producing many long stemmed flowers in various combinations of red and yellow. Each 20 cents; 2 for 35 cents.

5961 STANDHOLDER-Large flowers with stiff stems. Each 20 cents; 2 for 35 cents.

\section{GYPSOPHILA (Baby's Breath)}

$\approx 7030$ PANICULATA-Single; P.; 2 ft.; all summer; a very popular flowering plant, producing masses of small white flowers. Flowers may be cut and dried for winter bouquets. Each 20 cents; 2 for 35 cents.

\section{HELENIUM (Sneeze Weed)}

7041 HOOPESIl-P.; $1-3$ ft.; May-Sept. A rather coarse border plant bearing yellow flowers. They thive best in a rich, moist soil, with plenty of sunlight. Two year old plants 30 cents each.

\section{HEUCHERA (Coral Bells)}

$\therefore 7110$ SANGUINEA-P.; $11 / 2$ ft. ; July-Aug. Crimson scarlet flowers. Prefers an open situation. Suitable for rockeries. Each 35 cents; 2 for 65 cents.

\section{HIBISCUS (Rose Mallow)}

ROSE MALLOW-P.; $3-4$ ft.; Aug.-Sept.; do best in a moist soil. Have Hollyhock-like flowers. Very often the lower part of the root decays during the spring, but the plant will grow if the crown is sound. Starts growth very late.

7120 MIXED VARIETIES.

7121 CRIMSON EYE-Flowers white-or pink with dark centers.

7123 MOSCHEUTOS-Pink flowers.

7124 NEW GIANT FLOWERING-Mixed colors.

PRICES: EACH 20 CENTS; 2 FOR 35 CENTS; 2 YEAR OLD PLANTS, EACH 30 CENTS; 2 FOR 50 CENTS.

\section{HOLLYHOCKS}

Hollyhocks-B.; 4-6 ft.; August-September; no garden is complete without Hollyhocks.

7130 Single Varieties, mixed.

7131 Single Red.

7133 Single Yellow.

7134 Single Pink.

7135 Single Rose.

7136 Single Salmon.

7140 Allegheny, a fine selection.

7150 Double Varieties, mixed.
7151 Double Maroon.

7153 Double Newport Pink.

7154 Double Blood Red.

7155 Double White.

7156 Double Yeilow

7157 Double Rose.

7158 Dotble Salmon.

7165 Hybrids, double and single. 


\section{IBERIS (Perennial Candytuft)}

7190 GIBRATARICA-P.; 6-10 inches. An evergreen plant, covered with pinkish-white flowers in spring and early summer. Suitable for rockeries and edges. Each 20 cents; 2 for 35 cents.

\section{LINUM (Flax)}

7280 PERRENE-P.; 2 ft.; May-Aug. Similar to annual flax. Flowers blue. Each 20 cents; 2 for 35 cents.

\section{LUPINUS (Lupine)}

POLYPHILLUS-P.; $3 \mathrm{ft}$; all summer; flowers in spikes, foliage deeply cut and attractive.
7310 MIXED COLORS.
7312 ROSE.
7313 WHITE.
7315 ATROCOERULEUS-Blue.
7316 GOLDEN SPIRE.
7317 NEW HYBRIDS.

EACH 20 CENTS; 2 FOR 35 CENTS.

\section{LYCHNIS (Maltese Cross-Ragged Robin)} 7321 CHALCEDONICA-P.; 2 ft.; June-July. Ore of the best of old fashioned flowers. Flowers brick red, appearing in clusters.

7322 CHALCEDONICA ALBA-A white fiowered form of the above.

7325 HAAGEANA - Scarlet, dwarf, very fine.

7326 ARKWRIGHTII-A cross between Chalcedonica and Haageana, dwarf.

7327 FLOS CUCULI (Ragged Robin)-Rose pink flowers.

ANY OF ABOVE: EACH 25 CENTS; 2 FOR 50 CENTS.

\section{MYOSOTIS (Forget-Me-Nots)}

7380 FORGET-ME-NOTS-P.; 6-10 inches; all summer. Flowers light blue. Each 20 cents; 2 for 35 cents.

\section{PAPAVER (Poppy)}

$\therefore 7430$ NUDICAULE (Iceland Poppy)-P.; 2 ft.; all summer; flowers white, yellow and orange, many being double. Will last a long time as cut flowers. Mixed. Each 20 cents; 2 for 35 cents.

$\because$ ORIENTALE (Oriental Poppy)-P.; 3 ft.; JuneIuly. They produce magnificent effects in herbaceous borders and in shrubbery.

$\because 7441$ ORIENTAL RED.

EACH 20 CENTS; 2 FOR 35 CENTS; LARGE PLANTS 35 CENTS EACH.

\section{PENTSTEMON (Bearded Tongue)}

$\therefore 7470$ PUBESCENS-P.; 1 ft.; June-July. A very satisfactory plant for the hardy border. Wants plenty of sunlight. Flowers a rosy purple. Each 25 cents.

- BARBATUS TORREYI--See Number 6470 Chelone.

\section{PHYSALIS (Chinese Lanern)}

7540 FRANCHETTI-P.; $1-2$ ft. A plant grown for its bright colored seed pods. which resemble Chinese lanterns. Used for winter decorations. Each 20 cents; 2 for 35 cents.

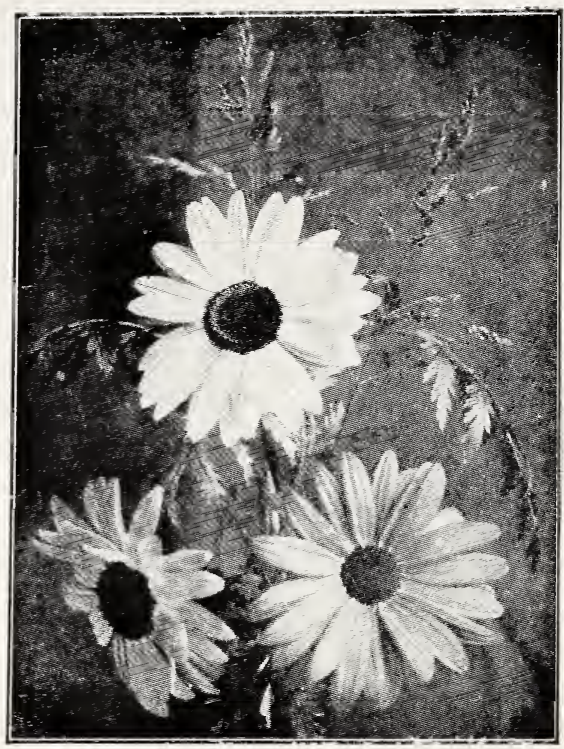

\section{PYRETHRUM ROSEUM}

\section{PLATYCODON (Balloon Flower)}

*7560 SPP.-P.; 1-2 ft.; June-Sept. Blue bell. shaped flowers. Should be planted on well drained soil. Each 20 cents; 2 for 35 cents.

\section{PYRETHRUM (Daisy)}

$\because 7640$ ROSEUM HYBRIDUM-Painted Daisy ; P.; 2 ft.; May-June. A valuable plant, producing long stemmed flowers in various shades of pink and red. Each 20 cents; 2 for 35 cents. Larga plants 30 cents and up.

7647 ULIGINOSUM (Giant Daisy) - $\mathrm{P}_{3} ;-3$ ft. fafll; large, daisy-like white flowers. Each 20 cents; 2 for 35 cents. Large plants 35 cents. 7648 ATRO-SANGUINEUM - Flowers supposed to be blood red. Each 25 cents.

7649 PYRETHRUM AUREUM (Golden Feather) -Tender perennial grown for its vellow foliage. Each 20 cents; 2 for 35 cents.

\section{RUDBECKIA (Purple Cone Flower)}

$\therefore 7670$ PURPUREA GRANDIFLORA-P ; 3 ft. ; September-October. A plant suitable for growing among shrubs. The crimson-purple flowers with drooping petals and large dark cone-like centers are similar to the smaller varieties of sunflowers. The center cones may be dried and used for decorating. Each 20 cents; 2 for 35 cents.

7671 FULGIA - 18 inches; similar to above flowers yellow. Each 20 cents; 2 for 35 cents.

$\approx 7675$ GOLDEN GLOW-P.: 6 ft. : August. Large yellow double flowers. Each 20 cents; 2 for 35 cents. 


\section{SALVIA (Meadow Sage)}

7681 AZUREA GRANDIFLORA-P.; 4 ft.; September-October; bears a great profusion of sky blue flowers. Each 20 cents; 2 for 35 cents.

7682 DARK BLUE-Later than the former Each 20 cents; 2 for 35 cents.

\section{SCABIOSA (Blue Bonnet)}

$\therefore 7721$ CAUCASICA-P.; 18 inches; June-Oat. light blue flowers on long stems. Each 20 cents: 2 for 35 cents.

\section{STATICE (Sea Lavender)}

$\because 7831$ LATIFOLIA-P.; large spreading panicles of deep blue flowers similar to Baby's Breath. May be dried and used in winter bouquets. Each 20 cents; 2 for 35 cents; large plants 35 cents each.

\section{THALICTRUM (Meadow Rue)}

7881 ADIANTIFOLIUM-P.; $1-3$ ft.; May. Has finely cut foliage, similar to Maiden-Hair Fern and plumes of small whitish flowers. Large plants 50 cents each.

7882 AQUILEGIFOLIUM-P.; 4 ft.; AugustJuly; leaves similar to Aquilegia. Plumes of lavender flowers. Large plants 50 cents.

\section{VERONICA (Speedwell)}

7960 SPICATA-P.; 2 ft.; July-August. A pretty herbaceous plant with blue flowers. Each 20 cents; 2 for 35 cents.

\section{VIOLA (Hardy Pansy)}

*VIOLA CORNUTA-Bedding Pansies-P.; 6 inches; spring until destroyed by heary frost in the fall.

7990 MIXED COLORS. Each 10 cents; 6 for 50 cents.

\section{RIBBON GRASS}

Leaves green and white striped. Useful for borders, edgings. Each 20 cents; 2 for 35 cents; large clumps each 50 cents.

\section{HARDY PHLOX}

No garden or border of perennial plants is complete without Phlox. Plant several plants in each group so as to obtain a mass of color. Phlox prefer a rich soil and a good supply of moisture. Root divisions, except where noted. Each 20 cents; 6 for $\$ 1.00$.

MISS LINGARD - Best early white, sometimes blooming until late in the fall.

MRS. JENKINS-Late; clear white.

WIJERS - White with red eye.

R. P. STRUTHERS-Carmine.

LOTHAIR-Lavender. Each 15 cents.

SIEBOLD-Orange scarlet.

\section{DWARF PHLOX}

PHLOX SUBULATA-A low growing Phlox with small flowers, blooming very early in the spring. Very desirable for rockeries. Pink or white. Each 20 cents; 2 for 35 cents.

\section{PEONIES}

Large plants ready to bloom. Each $\$ 1.00$. ANDRE LAURIE-Red. FLORAL TREASURE-Pink. FESTIVA MAXIMA-White

\section{IRIS}

BLUE-Large divisions, each 25 cents. Large plants 75 cents each.

MIXED VARIETIES-Each 20 cents, 2 for 35

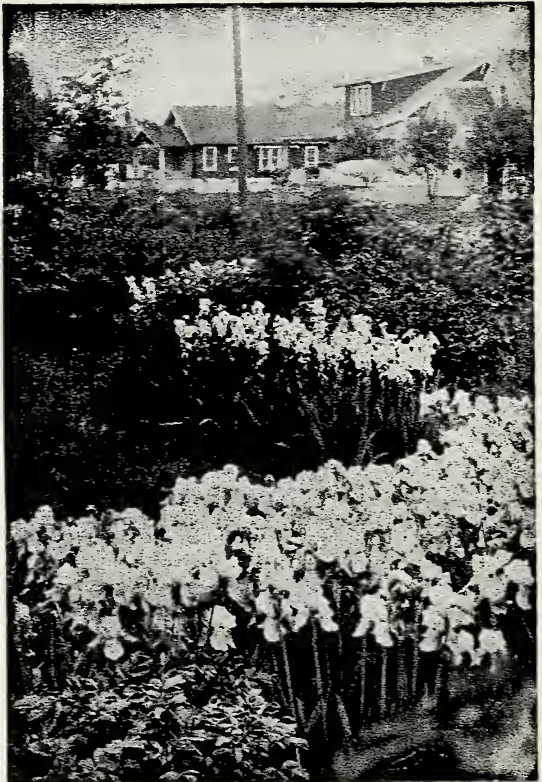

Showing Iris in the Border

\section{MISCELLANEOUS}

We have a few plants of each of the following varieties and will be glad to fi!l orders as long as the supply lasts.
ACANTHUS LATIFOLIUS.
ASTERS, Perennial.
DELPHINIUM, Red.
CHEIRANTHUS ALLIONI.
CENTAUREA, Red and yellow.
HEDYSARUM CORONARIA.
LIATRIS.
LEMON LILY.
SAPONARIA OCYMOIDES.
SALVIA ARGENTIA.
SEDUM.
SILINE ORIENTALIS.
YUCCA FILAMENTOSUM. 


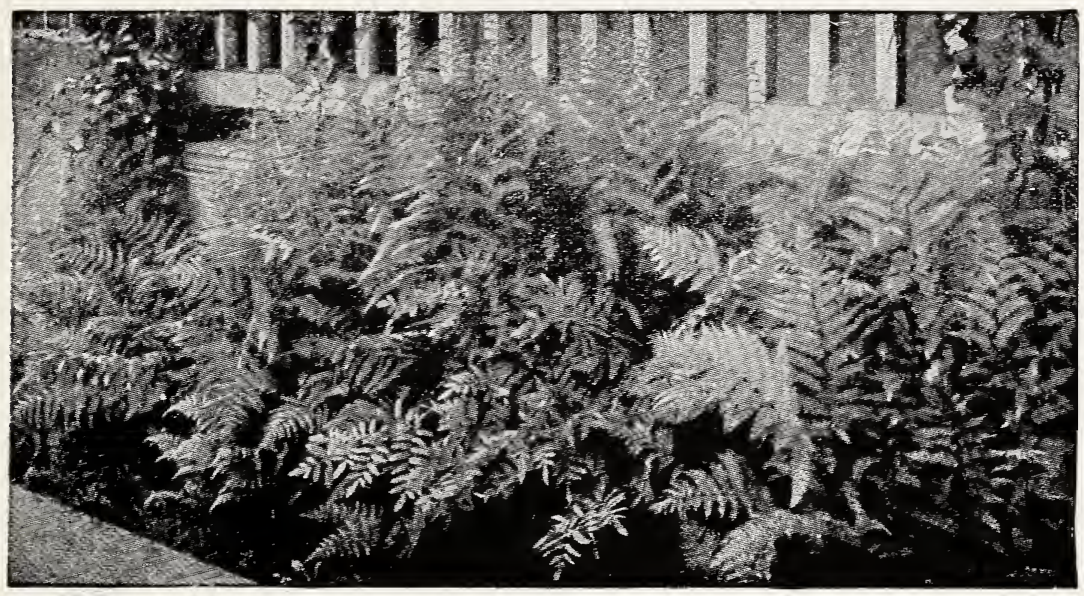

A FOUNDATION PLANTING OF HARDY FERNS

\section{HARDY FERNS}

Hardy Outdoor Ferns grow best in the shade or half shade and will do well in the border. They are just the thing for that shady place around your house where most flowers will not do well.

Of all the Hardy Ferns the Ostrich Plume, also called the Palm of the North, is perhaps the best as it grows the tallest and fastest of any Fern. It often has as many as fifteen fronds gracefully arranged, presenting an object more beautiful than many varieties of palms. The fronds under favorable conditions attain a length up to four feet.

Lady Fern is an extremely variable one, growing in all sorts of situations from low, moist woodlands. and shaded stream banks to dry woods and bushy clearings, but to develop its best forms it wants partial shade and a reasonable amount of moisture in the spring. The Lady Fern is a distinct, different type from the Ostrich and Osmunda.

The Interrupted Fern, known also as Claytons or Flowering Fern is considered one of the finest species for outdoor cultivation. It is highly individual in form and bearing and is superbly graceful. This variety will also do well in open places and on rocky banks.

These three Ferns represent three distinct types, not easily killed by neglect or mistreatment. Planted in groups among shrubbery, each variety separate, they come perhaps nearer to imitate their natural haunts than by artful arrangement in a formal garden.

\section{CULTURAL DIRECTIONS}

These Hardy Outdoor Ferns do not make satisfactory house plants; they will do best in shade or half shady spots in the garden and mixed in between shrubs in foundation plantings on the east and north sides of buildings. Some of these, like the Osmunda, Claytoniana, Lady and Sensitive Fern and Ostrich Fern will do reasonably well in considerable direct sunlight but will fade earlier than when planted in shade or half shade. They do best in light soil containing much vegetable matter or humus and covered with rotting wood shavings, peat or straw, which keep them from sprouting too early in the spring, preventing a late night frost from killing the young fronds.

Do not anply fresh manure nor artificial or commercial fertilizer.

Hardy Ferns should be planted when dormant any time between Sept. 1st and July 1st. They prefer a settled foundation and cool feet, consequently they do better the first year when planted in the fall. If late spring planting is followed by a dry, hot summer the fronds are likely to dry up in the middle of the summer the first season unless artificial watering can be given in abundance.

These roots are strong, well established, not less than 5 year old plants, with a lot of vitality stored up in their roots which wi:l keep them alive for a long time under adverse conditions. This refers especially to the Ostrich, the Osmundas, and Lady Ferns.

We offer the following special collections, carriage prepaid, for $\$ 5.00$ or one-half for $\$ 3$. By express, not prepaid, each collection $\$ 4.00$ or any one-lialf $\$ 2.25$. Or all four collections, 84 ferns in all. $\$ 15.00$. Any one Fern for 50 cents.

You can order by number and say one or onehalf collection and we will make no mistake. We have these ferns dormant almost to July 1st.

No. 1-General collection of the three varieties that have given universal satisfaction under all condi. tions anywhere, 8 Ostrich Plume, 4 Osmunda Claytoniana, 8 Lady Ferns.

No. 2-Special for dry, shady places, 10 Dagger Fern, 6 Hayscented, 6 Claytoniana.

No. 3-For moist, slady places, + Maiden Hair, 4 Christmas Fern, 4 Ostrich Plums, + Cinnamon, 4 Lady Fern.

No. 4-For wet ground - Mars's Slield Fern, 10 Sensitive Fern, 6 Royal Fern, + Cintoniana.

NOTICE: Allow from one to two weeks' time on a.l orders for Ferns. 


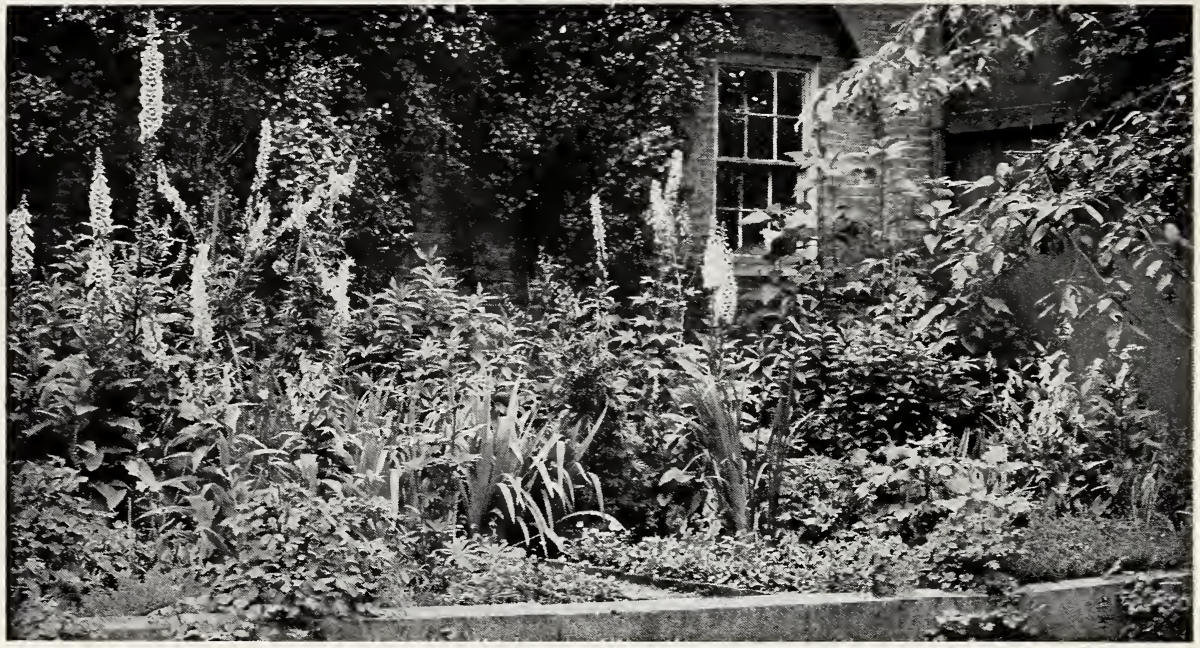

\section{CANNUAL FLOWERING PLANTS

\author{
FOR WINDOW BOXES AND BEDDING PURPOSES
}

Annual flowering plants complete their growth the first season, thus giving quicker results than many of the perennials and generally at lower cost. For these reasons they are especially desirable when planting a place that is rented for a short period. The taller kinds may be used in the place of shrubbery around the house, thus tying the building to the ground. Many of the Annual Plants such as Zinnias are very effective when used as a low hedge. When used in the more or less formal garden care should be taken to have the colors of the blossoms harmonize.

If the plants are being grown for cut flowers only, they should be planted in rows about two feet apart and each plant given plenty of room, good cultivation and an ample supply of moisture. Large flowers cannot be produced in a crowded and neglected garden. A garden of this kind is generally placed at the rear of the yard and is often secluded by shrubbery.

Our bedding plants are grown in flats and in pots. Flat grown plants, or in other words, plants grown in shallow boxes are very good plants and will give satisfaction if properly handled; but there is more danger of wilting at time of transplanting. Select short stocky plants rather than the tall, thin kind if you want the best results. Flat grown plants are easier to handle and take care of than pot grown plants while they are in the greenhouse and in the cold frames; consequently they are sold at a lower price than the latter.

Nany people prefer plants grown in pots because there is less danger of them wilting when they are transplanted. In most cases our pot grown plants are of the better varieties or in separate colors.

\section{AGERATUM}

Ageratum is one of the best bedding plants, growing about 1 to $1 \frac{1}{2} \mathrm{ft}$. high. It is also suitable for window boxes. The flowers are light blue, do not fade and are not spoiled by rain.

Flat grown plants from seed: 6 for 15 cents; 12 for 25 cents.

Plants from cuttings, $33 / 4$ inch pots. Each 20 cents; 6 for $\$ 1.00$.

\section{ALYSSUM (Sweet)}

Sweet Alyssum is a dwarf growing plant, covering the ground with a carpet of very small white flowers. It is an excellent border plant. If some of the seed pods are removed the plant will continue to bloom until very late in the fall.

Flat grown plants, 6 for 15 cents; 12 for 25 cents. ;

Plants from $2 \frac{1}{2}$ inch pots, in blossom; each 5 cents; 6 for 25 cents.

\section{ANTIRRHINUM (Snapdragon)}

Snapdragons have become very popviar the past few years, and are one of the finest plants for cut ilowers. The are growing semi-tall varieties, which grow about 18 inches high.

Flat grown plants, mixed colors only, 6 for 15 cents; 12 for 25 cents.

Plants of following varieties from 3 inch pots, each 10 cents; 12 for $\$ 1.00$.

CANARY BIRD-Yellow.

FIREBRAND-Orange Scarlet.

GLORIA-Rich deep rose.

MELROSE-Salmon pink.

\section{ARCTOTIS GRANDIS (African Daisy)}

This variety of African Daisy grows from 2 to 3 feet high. The flowers are white on top. purple beneath, and close up toward evening. The blooms will last about a week as cut flowers, but should be avoided for evening decorations.

Flat grown plants; 6 for 15 cents; 12 for 25 cents.

\section{ASTERS}

Everybody admires Asters. They make a fine display when grown in masses. We are growing only the Giant Branching type as they are probably the hardiest variety and resist disease better than many of the other varieties of Double Asters. 
Flat grow plants, mixed colors only; 6 for 15 cents; 12 for 25 cents.

Plants of following colors from 3 inch pots, each 10 cents, 12 for $\$ 1.00$.

Rose Pink

White

Lavender

Peach Blossom

IMPROVED ANEMONE FLOWERED ASTER

Flat grown plants, white or pink, 6 for 20 cents; 12 for 35 cents.

\section{SINGLE MARGUERITE ASTERS} ers.

Plants strong and rigorous; good for cut flow-

Flat grown plants, white, pink or red; 6 for 15 cents; 12 for 25 cents.

\section{BELLIS (English Daisy)}

The English Daisy is best grown as an Annual. It is a low growing plant and likes a shady place.

Flat grown plants, pink and white mixed, 6 for 15 cents; 12 for 25 cents.

\section{CALENDULA}

Calendulas or Pot Marigolds are free blooming plants growing readily in any good garden soil. We have selected what we believe to be two of the best varieties for the use of our customers, namely Orange King and The Ball. The latter has longer stems and is more desirable for cutting.

Flat grown plants, Orange King only, 6 for 15 cents; 12 for 25 cents.

Pot grown plants, in bloom, $33 / 4$ inch pots, each 25 cents.

\section{CARNATIONS}

The Margaret Carnations bloom the first season from seed.

Flat grown plants from seed of the Double Rose and Double Pink, 6 for 15 cents 12 for 25 cents.

\section{CELOSIA (Coxcomb)}

PRESIDENT THIERS-Dwarf habit with bronze foliage, and bright crimson combs.

PLUMOSA COCCINEA-Two feet. The crimson flowers resemble ostrich plumes.

Pot grown plants only; each 20 cents; 6 for $\$ 1$.

\section{ANNUAL CHRYSANTHEMUM}

They produce many daisy-like flowers in attractive shades and color combinations. The blossoms keep well after being cut. Single varieties in mixed colors.

Flat grown plants, 6 for 15 cents; 12 for 25 cents.

\section{CINERARIA (Dusty Miller)}

These white leaved plants are fine for borders and general bedding purposes. Grown for their beautiful, downy, silvery foliage.

Flat grown plants, 6 for 15 cents; 12 for 25 cents.

\section{COLEUS}

The Coleus is grown for its colored leaves rather than for the flowers. It is one of the finest plants for window boxes. We have sereral varieties.

Large plants from $33 / 4$ inch pots; each 25 cents. Smaller plants at lower prices.

\section{COBEA (Cathedral Bells)}

A rapidly growing rine, suitable for window boxes. Flowers, rose purple and shell shaped. Leares small.

Plants in $33 / 4$ inch pots, each 25 cents.

\section{COSMOS}

A late summer and fall blooming plant. Blooms suitable for cut flowers. Leaves very fine. A good plant to use as a background for other plants or to hide unsightly fences and places. Early flowering mammoth in mixed colors only.

Flat grown plants, 6 for 15 cents; 12 for 25 cents.

\section{DELPHINIUM (Larkspur)}

The improved Giant Hyacinth Flowered Annual Larkspur is an especially desirable plant for cut flowers. It grows about 3 feet tall. The graceful spikes of bloom continue until very late in the fall. In mixed colors only.

Flat grown plants, 6 for 15 cents; 12 for 25 cents.

\section{DIANTHUS (Annual Pinks)}

The Annual Pinks grow about one foot high and produce a great many double flowers which are suitable for cut flowers. Mixed colors only.

Flat grown plants, 6 for 15 cents; 12 for 25 cents.

\section{EUPHORBIA (Snow on the Mountain)}

Snow on the Mountain is grown for its striking foliage which is light green edged with white. It offers a striking contrast with other plants. Growing about three feet high. It is used in making bouquets.

Flat grown plants, 6 for 15 cents; 12 for 25 cents.

\section{GERANIUMS}

There is no better plant for beds, window boxes or cemetery use than the Geraniums. All our Geranium plants are continuous bloomers, many of the larger plants bearing two to four large blooms at a time. We have taken care to select our plants from only good stock.

Colors: red, pink, salmon and white.

Pot grown plants only; each 10 cents to 35 cents, depending upon size and age.

Green and White Leaved Geranium, used for borders, fron 3 inch pots. Each 10 cents; 12 for $\$ 1.00$.

\section{GODEIA}

We had some plants of Godita in our trial beds the past season and were very well pleased with them and recommend them as desirable plants for cut flowers. Grow in a rather poor soil and do not use any fertilizer. Cut before fully open.

Flat grown plants (double rose); 6 for 15 cents; 12 for 25 cents. $^{\text {nt }}$

\section{GOLDEN FEATHER}

As its name indicates Golden Feather has a yellow foliage. The plant is used in borders and edges. $\mathrm{II}$ e have seen it used as edgings to Geranium beds in some of the parks in St. Paul. It is a tender perrenial but is best grown as an annual.

Flat grown plants, 6 for 15 cents; 12 for 25 cents.

\section{LOBELIA}

This desirable plant grows about six inches tall and is covered with small blue flowers the entire season. May be used for ribbon bedding. edgings and general bedding.

Flat grown plants, 6 for 15 cents; 12 for 25 cents.

Plants from small po:s, each 5 cents; 12 for 50 cents. 


\section{MARIGOLD (African and French)}

The Marigolds are old time favorites. Their bright yellow blooms may be used as cut flowers. Tliey do best in a sunny location. The African Marigolds sometimes reach 5 feet in height while the French type are dwarfs, about 1 foot.

Flat grown plants, 6 for 15 cents; 12 for 25 cents.

\section{NIGELLA (Love in the Mist)}

Nigella proved very satisfactory in our trial garden. The leaves are very fine; flowers blue. The curious looking seed pods in shades of green and brown, when dried are suitable for winter bouquets and baskets.

Flat grown plants, 6 for 15 cents; 12 for 25 cents.

\section{Nicotiana (Sweet Scented Tobacco)}

The Nicotianas are grown especially for their sweet perfume. Easily grown. Flowers open toward evening. Two varieties, white and red.

Flat grown plants, 6 for 15 cents; 12 for 25 cents.

\section{PANSY}

The Pansy is a great favorite with most lovers of flowers. It appeals to personal feeling and is an inspiration to the gardener.

Our Pansies are grown from one of the best strains of seed and are sure to give satisfaction. All plants are transplanted and in bloom. Mixed colors, dozen 40 cents, 2 dozen for 75 cents.

\section{PENTSTEMON SENSATION (RED BEARDED TONGUE)}

We are growing this variety of Pentstemon as an annual because it has not proved hardy in our tests. It produces large spikes of red and white flowers.

Flat grown plants, 6 for 15 cents; 12 for 25 cents.

\section{PETUNIA}

Petunias are excellent for mass bedding, borders and window boxes. Even the dwarf sorts listed below are fine for window boxes.

Single, small flowering sorts, mixed colors, for general bedding purposes.

Flat grown plants, mixed colors, 6 for 15 cents; 12 for 25 cents.

Single Small flowered dwarf varieties, all grown in 3 inch pots and in blossom (after May 15).

IMPROVED ROSY MORN-Pink with white centers.

ROSE OF HEAVEN-Pink,

SNOWBALL-White.

ALDERMAN-Dark blue.

Each 10 cents; 12 for $\$ 1.00$.

BALCONY PETUNIAS FOR WINBOW BOX$\mathrm{ES}$, in blue, rose, white and red.

Plants from 3 inch pots, each 10 cents; 6 for 50 cents.

Other Varieties of Petunias grown in pots.

ROYAL PURPLE-Each 15 cents.

HOWARD'S STAR-Each 10 cents.

PINK GLORY-Each 20 cents.

RUFFLED GIANTS-Each 20 cents.

\section{PHLOX DRUMMONDI (Annual)}

One of the best bedding plants. Each plant bears many blossoms. Desirable for cut flowers. In mixed colors only.
Flat grown plants, 6 for 15 cents; 12 for 25 cents.

\section{RICINUS (Castor Bean)}

Strong growing plants $6.8 \mathrm{ft}$. high; suitable for center plants. Leaves purple, changing to a bronze green; seed spokes rosy crimson.

Pot grown plants, each 25 cents.

\section{SALPIGLOSSIS}

A very attractive annual with tube shaped blossonis.

Flat grown plants, mixed colors, 6 for 15 cents, 12 for 25 cents.

Pot grown plants of the following, each 10 cents, 12 for $\$ 1.00$.

\section{VELVETY RED. \\ PURPLE AND GOLD. \\ ROSE AND GOLD. GOLDEN YELLOW.}

\section{SALVIA}

Nearly everyone knows Salvia, the favorite plant for fall with its spikes of bright red flowers.

Flat grown plants, 6 for 15 cents; 12 for 25 cents.

Plants from 3 inch pots (a better variety than the above), each 10 cents; 12 for $\$ 1.00$.

\section{STOCKS}

Dwarf large flowering, 10 weeks. Mixed colors only.

Flat grown plants, 6 for 15 cents; 12 for 25 cents.

\section{SCABIOSA}

A very popular garden plant. Some people claim that it will take the place of Asters, as it is less subject to disease. The blooms have long stems and keep well after being cut.

Flat grown plants, mixed colors, 6 for 15 cents, 12 to 25 cents. Named varieties from 3 inch pots, each 10 cents; 12 for $\$ 1$.
AZURE FAIRY-Blue.
CHERRY RED.
PEACH BLOSSOM
WHITE.
ROSE FAIRY.

\section{TRITOMA (Red Hot Poker)}

Tritonı is generally considered as a perennial, but it has not proved hardy with us. We have been informed that if planted very early it will bloom the first year. Plants grow 3-4 feet high and have bright red flowers.

Flat grown plants, 6 for 15 cents; 12 for 25 cents.

\section{VERBENA}

The Verbena is a fine plant for beds, borders or window boxes. Our plants are grown from one of the best strains of Verbena seed.

Flat grown plants, mixed colors, 6 for 15 cents, 12 for 25 cents.

Plants from 3 inch pots, each 10 cents; 12 for $\$ 1$.

\section{ZINNIA}

This popular flower needs no description. It is suitable for borders or beds. We are growing three choice classes, Giant Flowered, Dahlia Flowered. and a dwarf type. 
Giant Flowered, mixed colors only, flat grown plants, 6 for 15 cents; 12 for 25 cents.

Dahlia Flowered, blooms larger than in the Giant Flowered.

Named rarieties only:-

$\begin{array}{ll}\text { Crimson Monarch. } & \text { Golden State. } \\ \text { Oriole. } & \text { Exquisite. Rose. } \\ \text { Old Rose } & \text { Polar Bear. }\end{array}$

Flat grown plants, 6 for 20 cents; 12 for 40 cents.. Plants from 3 inch pots, each 10 cents.

Dwarf Type-1 ft. high. Flowers scarlet and about 1 inch across. A fine border or edging plant.

Flat grown plants, 6 for 15 cents; 12 for 25 cents.

\section{ANNUAL EVERLASTINGS (STRAWFLOWERS)}

HELICHRYSUM-The most popular ererlasting. Daisy or Aster-like flowers. In the following colors: yellow, red, rose and white.
XERANTHEMUM - A pretty everlasting, bearing an abundance of rose, purple and white flowers. STATICE-Sometimes called the California Strawflower. We have grown it in our gardens successfully for a number of years. Colors, yellow, rose, and blue.

Prices for above Strawflowers, 6 for 15 cents; 12 for 25 cents.

\section{PERENNIAL EVERLASTINGS \\ BABY'S BREATH No. 7030. \\ SEA HOLLY No. 6910. \\ CHINESE LANTERN No. 7540. \\ CONE FLOWER No. 7670. \\ BASKE'T OF GOLD No. 6100 .}

\section{DRIED FLOWERS}

Next fall we will have a limited supply of rarious kinds of Dried Flowers for winter bouquets and baskets.

\section{VEGETABLE PLANTS}

\section{WASHINGTON ASPARAGUS ROOTS}

Nearly every one wants a small Asparagus bed in his garden. Washington Asparagus is free from the dreaded disease known as rust. and is now the leading variety. Twenty-five plants will give enough shoots for an ordinary family. Plant them 2 feet apart each way. Three year old roots. dozen 35 cents; 2 dozen for 65 cents. Extra large selected roots, dozen 50 cents.

\section{MARY WASHINGTON ASPARAGUS ROOTS}

The Mary Washington strain of the Washington Asparagus is considered superior to the ordinary strains. The seeds from which our plants of this strain were grown was selected from our own field of Asparagus, which produces a wonderful crop of large shoots. Two year old plants, dozen 35 cents; selected roots, dozen 50 cents.

\section{RHUBARB ROOTS}

Every home garden should have one or two plants of Rhubrab. Large roots (divisions) of a good red variety; each, 50 cents.

\section{CABBAGE (EARLY VARIETIES)}

GOLDEN ACRE-The best early cabbage, transplanted plants, grown in hot-beds, but well hardened, ready May 1. Dozen 20 cents; 2 dozen 35 cents.

RED CABBAGE-Dozen 15 cents; 2 dozen for 25 cents.

\section{(LATE VARIETIES)}

DANISH BALL HEAD-2 dozen for 15 cents; 100 plants for 50 cents.

\section{CAULIFLOWER}

Early, started in hot beds, transplanted, and well hardened. Needs rich ground. Ready May 20. Dozen 20 cents.

\section{CELERY}

GOLDEN SELF-BLANCHING - Transplanted, Dozen, 20 cents; 100 for $\$ 1.25$.

\section{CELERIAC}

ROOT CELERY. Used for flaroring soups, or may be cut very fine and used in salads. Some people like it cut into small cubes, boiled and served with white sauce. Same price as Celery.

\section{EGG PLANT}

Egg Plant is not nearly as popular as it should be probably because very iew people know how to serve it. Try this recipe.

Peel and slice one medium sized egg plant. Boil in slightly salted water until tender. Drain and squeeze out all water. When cool add four crackers rolled fine and one egg. Salt and pepper to taste. Beat all together, make into patties and fry brown in butter and lard. Serve hot.

Transplanted plants, dozen 25 cents.

\section{KOHL RABI}

Seedlings. Dozen 10 cents; 3 dozen for 25 cents.

\section{PEPPERS}

LARGE SWEET PEPPERS-Suitable for stuffing and salads.

HOT PEPPERS-For flaroring.

Transplanted plants, dozen 20 cents; 2 dozen for 35 cents.

\section{TOMATOES}

All plants transplanted and well hardened.

EARLIANA-We have a good strain of Earliana. the best early tomato.

MARGLOLE-The new rariety of tomato that excels all other medium season tomatoes. Fewer seeds than most varieties.

PONDEROSA or Beefsteak Tomato-A large meaty tomato liked by many people.

GOLDEN QUEEN-A large yellow tomato.

YELLOW PLUM-Small plum shaped tomatoes.

Any of the above, dozen 25 cents; 100 plants for $\$ 1.75$.

Pot grown plants to order only. Must be ordered with cash payment before April 15.

\section{HERBS}

Parsley, Thyme, Sweet Marjoram, Sage, Summer Savory. Each kind, 6 for 15 cents. 


\section{OUR TEN BEST HARDY PLANTS FOR CUT FLOWERS}

Columbine

Boltonia

Shasta Daisies

Larkspurs

Coreopsis
Phlox

Bearded Tongue

Scabiosa

Painted Daisy

\section{HARDY PLANTS FOR SHADY PLACES}

Bleeding Heart

Rosy Milfoil

Violas

Monkshood
Anchusa

Lily of the Valley

Canterbury Bells

Harebell
Gaillardia

\section{HARDY PLANTS FOR GRAVES}

Pinks

Gaillardia

White Daisy

Bearded Tongue

Shasta Daisy

Snow in Summer

Coreopsis

Forget-Me-Nots

Painted Daisy

Chinese Larkspur

Butterfly Larkspur

Hybrid Sweet William

Peonies

Phlox

\section{PLANTS SUITABLE FOR ROCKERIES} (HARDY PLANTS)

Basket of Gold

Thalictrums

Columbine

Rock Cress

Dwarf Larkspur

White Daisy

Pinks

Candytuft

Plumy Bleeding Heart

Harebell

Corn Flower

Baby Breath

Iceland Poppy

Bearded Tongue

Violas

Sedums

Phlox Subulata

Hardy Marguerite

Peach Bells

Euphorbia

\section{HARDY WHITE FLOWERS}

6012 The Pearl

6180 Rock Cress

6346 White Harebell

6460 Snow in Summer

6575 Shasta Daisy

6590 White Daisy

$6591 \mathrm{Hartje}$ and Elder Daisy

6630 Lily of the Valley
6667 Larkspur

6706 White Garden Pink

6750 White Sweet William

7313 Lupines

7322 White Maltese Cross

7647 Giant Daisy

7990 White Violas

\section{HARDY PINK FLOWERS}

6011 Rosy Milfoil

6163 Columbine

6312 Pink Boltonia

6343 Canterbury Bells
7110 Coral Bells

7123 Hibiscus

7134 Hollyhocks

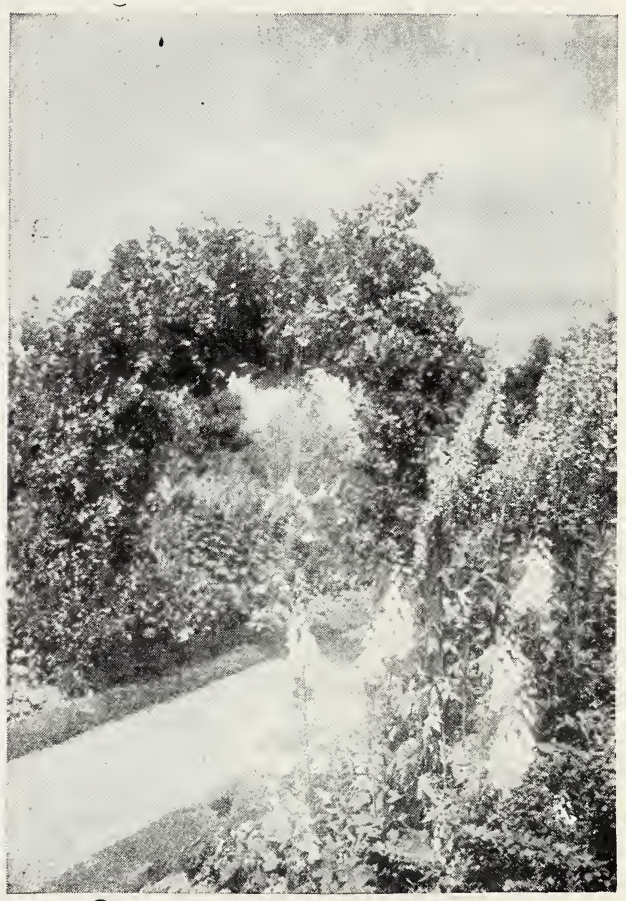

\section{(ANNUALS)}

Ageratum

Alyssum

Margueritte Asters

English Daisy

Golden Feather

Nigella

Petunia

Verbena

Larkspur
Pinks
Cosmos
Dusty Miller
Lobelia
Red Bearded Tongue
Phlox
Dwarf Zinnias

\section{HARDY BLUE FLOWERS}

6020 Monkshood

6121 Anchusa

6161 Columbine

6280 Baptisia

6341 Canterbury Bells

6345 Harebell

6360 Peach Bells

6430 Corn Flower

6650 Larkspur
6910 Sea Holly

7280 Flax

7315 Lupines

7470 Bearded Tongue

7560 Balloon Flower

7721 Scabiosa

7960 Speedwell

7990 Blue Violas

7312 Lupine

7640 Painted Daisy

7670 Purple Cone Flower

6705 Cliff Pink

6752 Sweet William

6801 Bleeding Heart

Phlox

\section{HARDY YELLOW FLOWERS}

6100 Basket of Gold

6101 Madwort

6140 Hardy Marguerite

6162 Columbine

6630 Coreopsis

7041 Sneeze Weed

\section{HARDY RED FLOWERS}

6725 Hybrid Sweet William

6960 Gaillardia

(Red and Yellow) 7441 Oriental Poppy
7430 Iceland Poppy 7671 Yellow Cone Flower 7675 Golden Glow

6777 Sweet Williams

7131 Hollyhocks

331 Maltese Cross 


\section{IHIS PDUDDN GDOD FOR TD EFNTS}

COUPON when presented at time of making purchase (at our Nursery only) will be accepted for FIFTY CENTS on any order amounting to $\$ 5.00$ or more.

\section{Choice Perennials} for $\$ 2.50$

Send us \$2.50 and we will send you any one of the following collections of plants by express.

\section{A. 18 PERENNIAL PLANTS SUITABLE FOR CUT FLOWERS.}

B. 18 RED FLOWERED PLANTS.

C. 18 PINK FLOWERED PLANTS

D. 18 BLUE FLOWERED PLANTS.

E. 18 YELLOW FLOWERED PLANTS.

F. 18 PERENNIAL PLANTS SUITABLE FOR ROCERIES.

\section{Dozen Annuals for $\$ 2.00$}

Send us $\$ 2.00$ and we will send you 10 DOZEN ANNUAL PLANTS SUITABE FOR GENERAL BEDDING PURPOSES.

IF WANTED BY PARCEL POST ADD 40 CENTS FOR POSTAGE AND PACKING.

It plants become infected with aphids (plant lice) spray them with a solution of water and tobacco extract such as Black Leaf or Nicoiume.

For insects that eat the foliage spray with a solution of water and Paris Green or arsenate of lead.

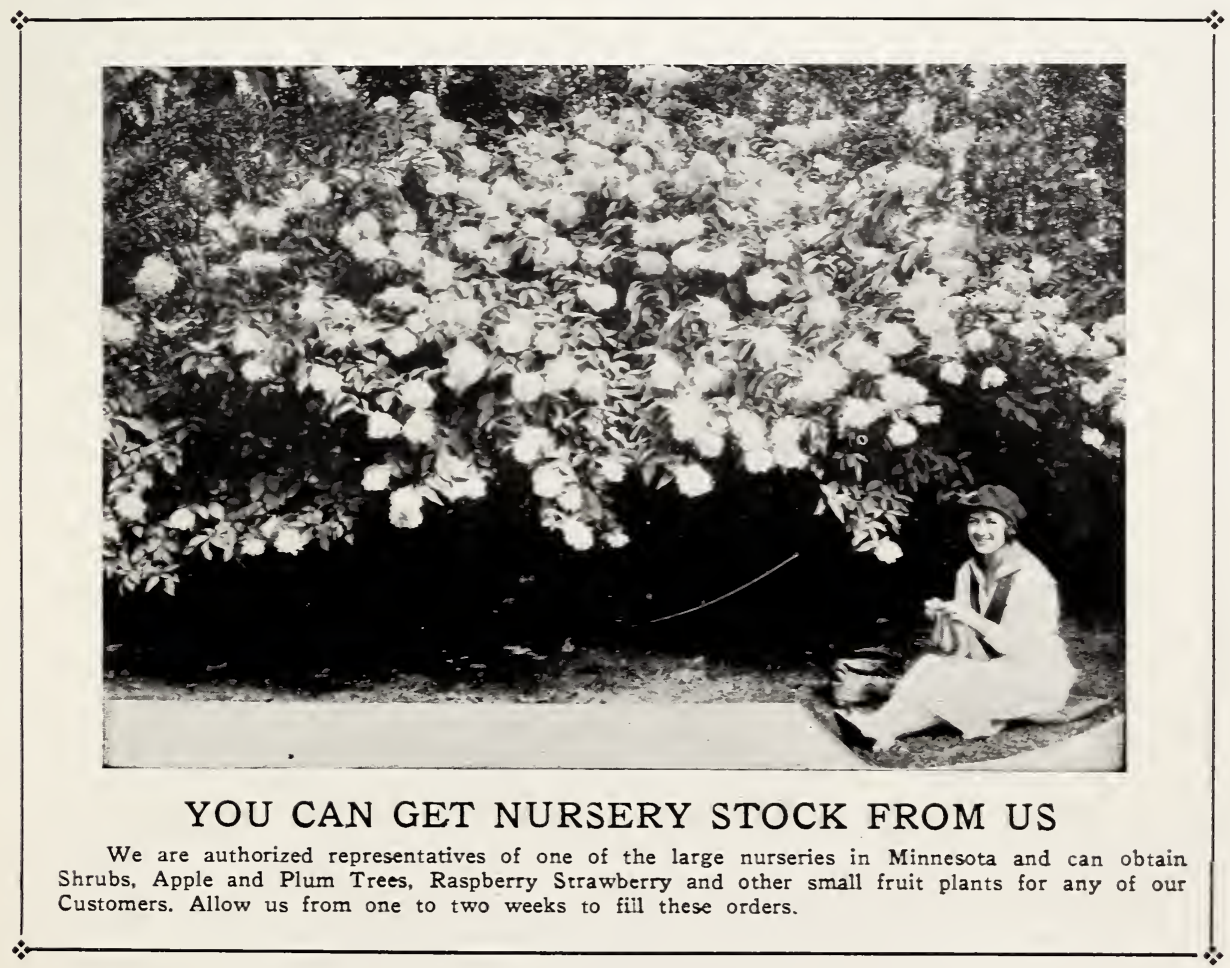




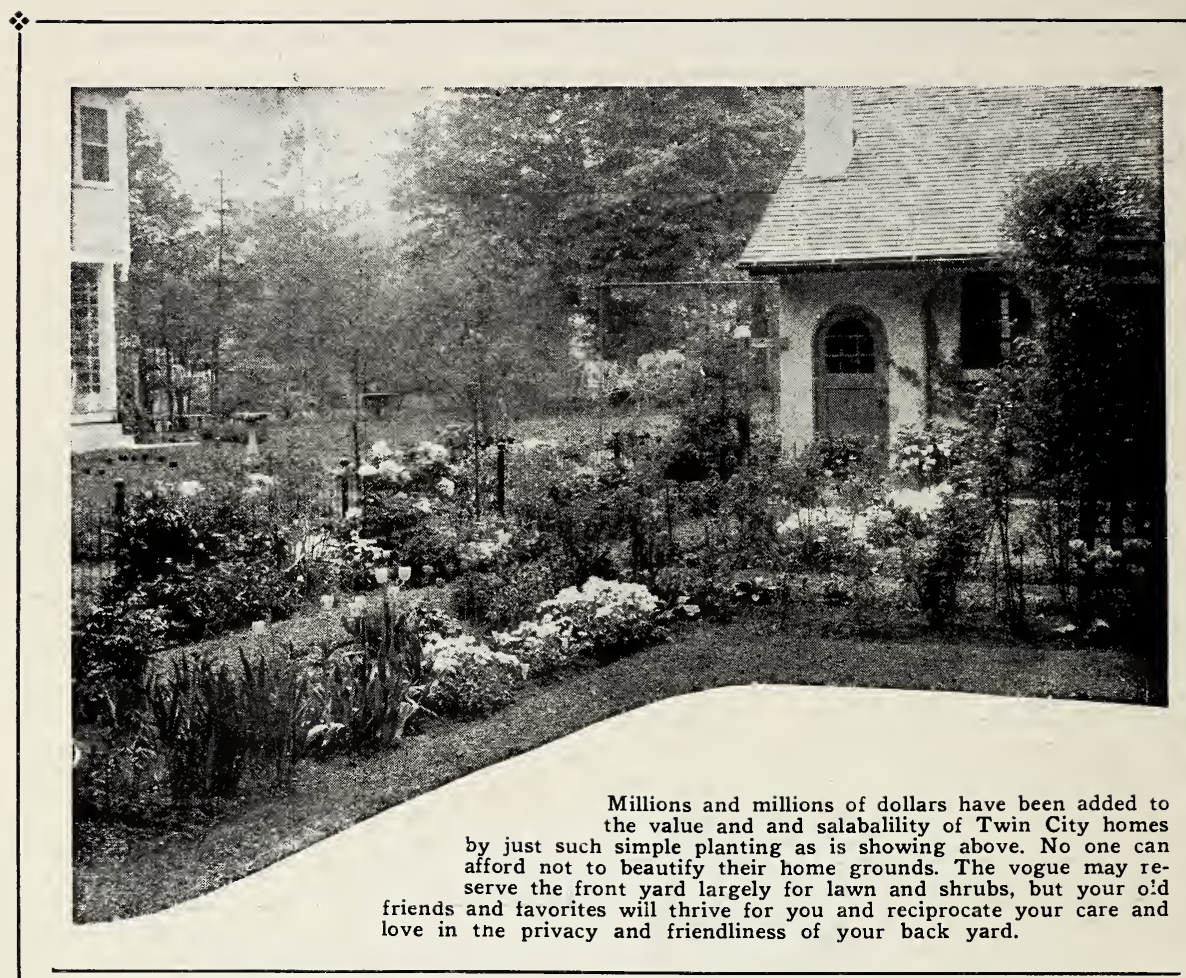

ALFRED G. PERKINS

C. EDWARD PERKINS

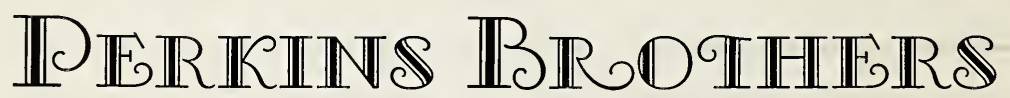

GARDENS:-ST. PAUL, STILLWATER ROAD (Highway 45), RAMSEY COUNTY, MINN. $51 / 2$ Miles From St. Paul Court House

Telephone To 68945

PLEASE NOTE:-That while Our Postoffice Address is North St. Paul, Customers Desiring to Visit Our Gardens Do Not Go There to Find Us, But Follow Route Indicated Above.

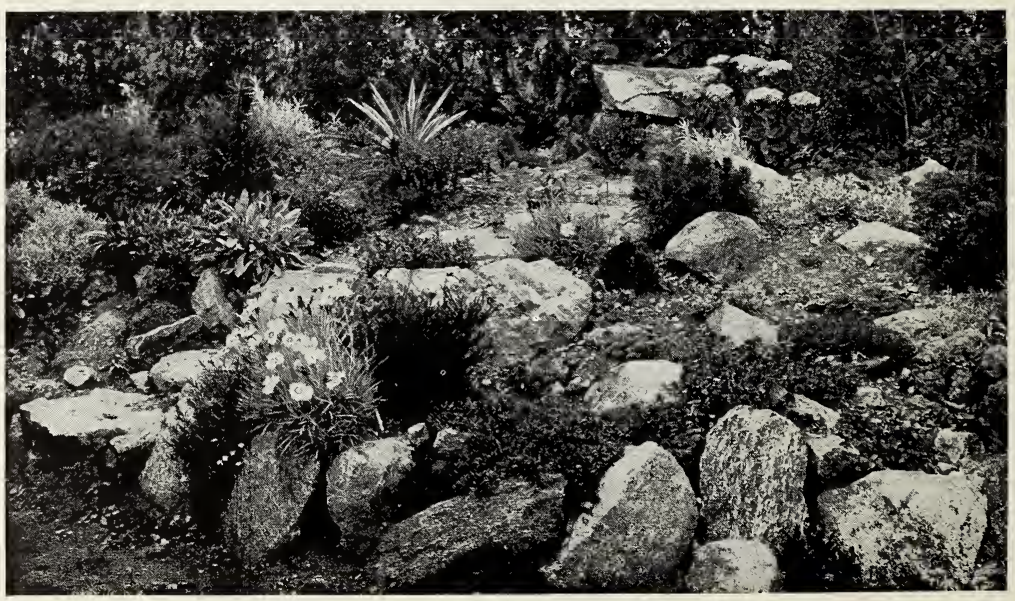

Rock Gardens are becoming increasingly popular with flower lovers. Informal Rock Gardens can be laid out in so small a space as a city lot. They give plenty of opportunity for all your ingenuity, and very unusual effects may often be rather easily obtained. 